\section{ACRL}

Guidelines

\title{
Guidelines for University Undergraduate Libraries
}

\section{The final approved version}

$\mathbf{U}$ ndergraduate libraries have been established with the primary mission of meeting the library and information needs of undergraduate students enrolled in the large university environment. These guidelines identify the principal factors influencing the development and maintenance of undergraduate library services and collections. In addition, a review of these factors as they relate to local circumstances should assist in evaluating the need for a separate undergraduate library and enable assessment of whether an undergraduate library should be established or continued.

\section{Campus environment}

Library systems at large universities generally consist of a main university library plus several branch or special libraries. The large campus environment often defines the quality of the library in terms of the strengths and size of the research collection. Concentration of the main and branch libraries is frequently on the needs of specific fields or departments of study at a research level. These factors create an intimidating environment for many undergraduate students. The needs of academic library users fall on a spectrum with use of introductory research materials and instruction in the research process at one end, and primary source materials and bibliographic services at the other end. Undergraduate libraries concentrate on the former.

\section{Primary clientele}

Undergraduate students enter the university with varying levels of experience and intorma- tion skills and share many of the following characteristics:

1) They are beginning to acquire the research skills needed to exploit the research library's potential.

2) They need a user-friendly environment where assistance is offered and questions are encouraged.

3) They need to be introduced through library instruction, either one-on-one or through coursework, to the academic nature of the services and resources available in university libraries.

4) They are most often enrolled in courses where assignments have short deadlines requiring just-in-time library services. These courses often have large enrollments.

\section{Other clientele}

The undergraduate library may also serve the instruction and information needs of university staff and faculty, as well as members of the civic community.

\section{Communications}

In undergraduate libraries, the goal of all communications is assuring the effective provision of library services to all clientele. Undergraduate libraries focus on two types of communication: a) communication that informs or gives instruction about library services and use, i.e. public awareness and library instruction, and b) communication that provides information directly, i.e., reference services.

It is the responsibility of personnel in unclergracluate libraries to communicate effectively with students, faculty, colleagues, and library and university administrators about library services and collections available to and/or needed by undergraduate students. Also, personnel in undergraduate libraries promote use of library 


\section{Creating the Guidelines}

In 1993 the ACRL Undergraduate Librarians Discussion Group began work to update the 1987 Model Mission Statement of a University Undergraduate Library and to change it to guidelines. Revisions were discussed and amended in a series of meetings at three ALA conferences between 1993 and 1994. The resulting draft was submitted to the University Libraries Section (ULS) Executive Committee which then appointed the Ad Hoc Committee to Review Draft Guidelines for University Undergraduate Libraries. Members were: Paula Walker, chair, University of Washington; Barton Lessin, Wayne State University; Donna Senzig, University of Wisconsin-Madison; and Louise Sherby, University of Missouri, Kansas City.

After review by the committee, the draft Guidelines were published in the May 1995 C\&RL News, and a hearing was announced, to be held at the

services through advocacy and ongoing interaction with university groups who work with undergraduate students and their curricula.

\section{Programs}

To facilitate academic success, undergraduate libraries must provide access to a broad range of information resources. This access inclucles reference and referral services, orientation, and bibliographic instruction. Teaching students the critical thinking skills necessary for using a library is a basic service provided by the personnel of undergraduate libraries. The teaching programs of undergraduate libraries are varied and innovative. They include teaching by personal contact and through the preparation and use of instructional materials in various formats. They include formal group instruction and informal, unstructured contacts with students. Reference, library instruction, and orientation activities are appropriate for all levels and types of library users. Undergraduate libraries provicle a laboratory for clientele to acquire information literacy skills: identification of needed information, effective and ethical use of intellectual and physical resources, and knowledge of when to ask for help and the confidence to do so. Undergraduate libraries serve as a gateway to all future library inquiry, preparing students not merely for graduate work and research but also teaching them to use information sources as citizens, as consumers, as professionals, and for recreational purposes.

Reference and referral service for undergracluates often involves not only answering specific questions, but also personalized instruc-
1995 ALA Annual Conference in Chicago. Those who could not attend the hearing were invited to send comments or suggestions to the committee chair. At the hearing, those present made several suggestions to improve the draft Guidelines, which the committee accepted. After making the changes, the Ad Hoc Committee submitted the revision to the ULS Executive Committee at the 1996 ALA Midwinter Meeting, and the new version was approved. Barton Lessin took the Guidelines to the ACRL Standards and Accreditation Committee for review and approval in March 1996, and they were approved without change. The ACRL Board approved the new Guidelines for University Undergraduate Libraries at the ALA Annual Conference at New York in July 1996. The ALA Standards Committee completed its review and approved the document at the 1997 ALA Midwinter Meeting.

tion in the methods of identifying and retriev ing library materials. Supplemental to this personal contact is the provision of database interfaces, bibliographies, and other aids designed to introduce undergraduates to the materials available in the library and to guide them in finding the materials. The reference service provided by undergraduate librarians is a referral service to the wide variety of resources in the library system and beyond. Referrals may also help undergraduates become aware of branch or specialized libraries, and campus supportive services including academic, financial, writing, and counseling services.

Orientation activities acquaint undergraduates with the facilities and services of the library system. They include activities such as the distribution of maps and informational materials which describe the library system and the resources and services of the individual libraries within it, staff-conducted tours for groups, and self-guided tours. Orientation may also include public relations activities to help students become aware of the information resources available within the university community or on any information network.

Library instruction programs should improve the ability of students to make effective use of the library collections, services, and staff, and should include instruction in the use of online electronic sources as well as traditional print formats. Instruction may be offered as part of coursework in an academic subject or interdisciplinary program, in a separate course on library skills, in workshops and term-paper clinics, and through point-of-use aicls in the library. 


\section{Resources}

Effective undergraduate libraries require ad equate resources to accomplish their missions. Implicit in the creation of an undergraduate library is a commitment to funding its development, ongoing services, and growth while maintaining library services for the entire academic community. Standards of service in undergraduate libraries shoukl be comparable with other library services offered at the university even if access, personnel, level of collecting, and programs differ significantly.

\section{Personnel}

The personnel of undergraduate libraries have the knowledge and abilities to ensure effective management and use of the services and collections. In general, undergraduate libraries require librarians as well as support and parttime staff, depending on the size of the undergraduate population at the institution. The ability to interact on a one-to-one basis with a diverse clientele in a friendly and instructive manner is essential.

Personnel in undergraduate libraries require diversified backgrounds in order to meet the teaching and learning needs of users. Abilities needed include: teaching and knowledge of instructional methods and learning styles; excellent communication skills; and understanding and expertise in information-seeking skills. Personnel require flexibility and should be encouraged to take risks and develop innovative programs.

Undergraduate librarians should participate in appropriate professional organizations to assure awareness of special issues affecting undergraduate library services.

\section{Collections}

Undergraduate libraries acquire and provide ready access to information resources to meet the needs of their primary clientele with focus on the institution's curriculum. 'The value of collections in undergraduate libraries is measured by their usability as well as quality and size. Online electronic sources, both bibliographic and full text, form a significant part of the information network needed by undergraduates. Collection and access policies should be written and readily available.

Collection policies for undergraduate libraries consider the following:

1) Because many undergraduate courses require large numbers of students to use the same library materials, direct curriculum support will be provided through reserve collections and through purchase of multiple copies of items with high demand.

2) Undergraduate libraries provide effective access to information resources through reference sources in a variety of formats. Reference collections in undergraduate libraries should concentrate on the more standard and interdisciplinary indexes and sources. Periodical collections should emphasize the titles covered by these indexes.

3) Subject coverage of collections in undergraduate libraries encompasses a broad range of disciplines to offer the information needed for papers, speeches, and projects required in the wide variety of courses taken by undergraduates. More specialized and advanced needs will be met by specific referral to other library sources on campus.

4) The library experience of undergraduates should encourage them to seek information of personal interest. Collection policies should include access to information on current events, cultural interests, careers, and recreational reading, among others, to encourage exploration of information resources as a part of everyday life. Because of the special nature of undergraduate libraries, collection policies should include withdrawal practices. Collections should be dynamic and responsive to the needs of a changing curriculum and clientele.

\section{Effective learning environment}

Undergraduate libraries have facilities that promote effective and interactive access and use of information resources for all users. Safe, comfortable, well-lighted, clean space with adequate and appropriate seating should be provided to ensure effective use of the library's resources, including electronic formats. In physical planning for facilities, undergraduate libraries provide for small group and instructional use. Also, undergraduate libraries consider study space needs in allocation of seating and space, with attention to reserve collections and the residential environment of the institution. Undergraduate libraries establish hours of access, circulation policies, and other rules to meet the needs of their primary clientele.

\section{Evaluation}

\section{Performance measures}

Institutions establishing or maintaining an undergraduate library or providing undergradu- 
ate library services should apply the basic principles described in "Standards for the Evaluation of University Library Performance" (CERL News, September 1989, pp. 679-91). Because of the unique role of undergraduate libraries, the criteria for performance review and method of evaluation may be influenced by the overall library system's specific mission. Criteria for evaluating undergraduate libraries include:

1) Services. The usefulness of an undergraduate library is determined by the effectiveness and quality of the services provided in support of the undergraduate programs of the institution.

a. Do the services offered meet the information needs of the undergraduate students, and the faculty and staff who work with them?

b. Are user studies, statistics, and other measures of quantity and quality collected and utilized effectively?

c. Are library instruction programs available and funded adequately for the support of coursework?

d. Are staff adequately trained and compensated? Is staff development encouraged and supported?

e. What is the ratio of public services staff to the number of primary clientele? Is this an acceptable ratio?

f. Are additional services needed?

g. Are new services, which are needed by users, anticipated and implemented?

2) Collections and access. There is no absolute standard for the size of a collection in undergraduate libraries. The essential criterion is that the collections (or access to information outside of the collection) adequately support the needs of the primary clientele. The collec tion policy should adequately describe the collection goals and be evaluated with the following factors considered:

a. Does the collection profile adequately support the undergraduate curriculum?

b. Does the size and depth of the collection adequately support the size and need of the undergraduate population?

c. Are materials appropriately available and accessible for reserve users?

d. Are collections effectively included in the catalog? Are comparable standards of bibliographic access followed for undergraduate library collections as in the overall library system? e. Are collections housed and arranged efficiently and effectively for use by the primary clientele?

f. Are collections available and accessible to all users? Do circulation policies and practices permit effective access for users?

g. Are access policies posted to ensure that all users are aware of services and restrictions?

h. Do appropriate withdrawal policies and practices exist which adequately address the need for collection maintenance?

i. Are interlibrary loan and other documentdelivery services provided for undergraduates to give them access to materials not owned by the institution?

j. Do undergraduates have adequate access to electronic networks for accessing information?

3) Environment. Undergraduate libraries require appropriate facilities to provide the services and collections necessary to accomplish their missions.

a. Is the facility safe and environmentally controlled?

b. Are materials adequately safeguarded against loss, mutilation, theft, or other damage?

c. Is adequate equipment and technical support available?

d. Is appropriate seating and user space available?

e. Is space appropriately allocated for use including group and instructional use, study, research, use of information technologies?

f. Are facilities accessible to all users?

g. Does space allow for cooperative programs with other library and campus units?

\section{4) Adequacy of the budget.}

a. Is the budget comparable to other undergraduate libraries at comparable institutions?

b. Does the budget support appropriate levels of staffing?

c. Does the budget provide adequate support for baseline services?

d. Does the budget adequately support the collection policy to provide materials or access to materials in support of undergraduate students library needs?

e. Is the budget flexible enough to support necessary new programs and innovations, including integration of new technologies and instruction programs?

(Guidelines cont. on page 341) 


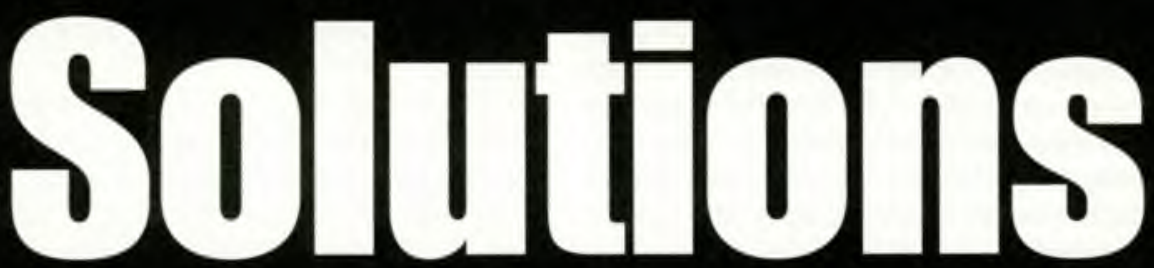

\section{Some Say It. Most Need Them. Few Have Them. At The Library Corporation (TLC), We Deliver Them.}

FOR MORE THAN 20 YEARS, TLC has been serving the library industry, delivering innovative client solutions, with superior customer service. We are the same company that proudly developed BiblioFile,

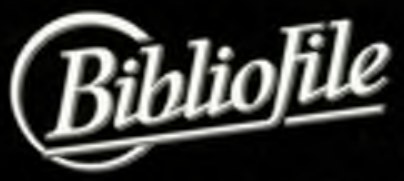
now installed in more than 7,000 libraries nationwide. The same company that delivered the world's first commercial application of the CD-Rom. And, the same company that pioneered library automation services over the

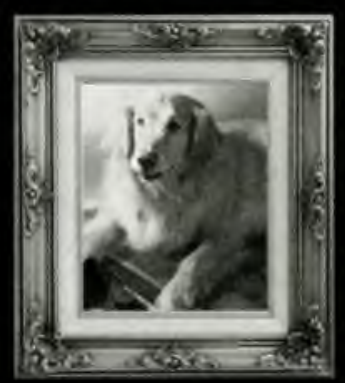
World Wide Web - from its infancy. Our BiblioFile ITS for Windows" set the standard for Z39.50 bibliographic access over the Internet. And, TLC's new integrated client server system, and TLC's new Inter-Library Loan service use the Internet for communications.

Much about us is both new, and not new. What's new is our name, TLC. Our corporate mission statement: "Solutions that Deliver." And our Web address: http://www. TLCdelivers.

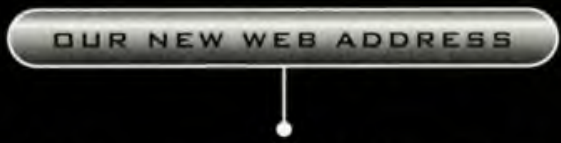

http://www.TLCdelivers.com

What's not new is our commitment to developing customized solutions for library automation needs worldwide.

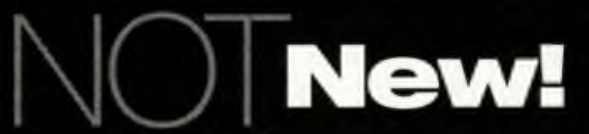

Our superior customer service. Our phone number: 800-325-7759. Our headquarters in Research Park.

TLC. Committed to delivering solutions that enable libraries to provide a more rewarding experience for their patrons. Most Need Them. Few Have Them. At The Library Corporation (TLC), We Deliver Them.

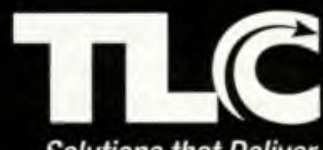

Solutions that Deliver 
Ronald Heckart. chair of the award committee, said, "Professor Taylor has a long and distinguished career of blending librarianship, law, and computers. She is a national and international leader in law library automation, a true pioneer in the field."

Taylor began her ca-

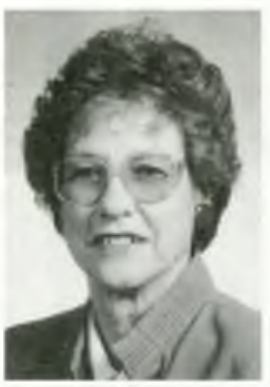

Betty Taylor reer in 1950 as an assistant in the library, then became assistant law librarian, acting law librarian, law librarian, and acting dean at UF.

In 1994 Taylor became the first woman to be named to an endowed professorship at the University of Florida and previously was named first distinguished Alumna of the Florida State University Library School.

The award, $\$ 1,000$ and a citation, is donated by Congressional Quarterly and will be presented at the LPSS program, Sunday, June 29, at 4:00 p.m., during the ALA Annual Conference in San Francisco.

\section{Raine and Stalker win award for best article in RBML}

Henry F. Raine and Laura Stalker are the winners of the 1997 Rare Books and Mamuscripts Librarianship ( $R B M L)$

Award for best article for "Rare Book Records in Online Systems" (volume 11:2, 1996)

Raine is head of technical services at the Folger Shakespeare $\mathrm{Li}$ brary in Washington. D.C. His other positions there have included assistant head of cataloging and senior cataloger.

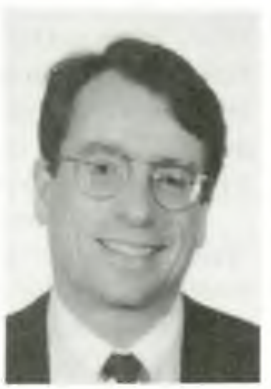

Henry F. Raine
He also served as an ALA Library Fellow at the National Library of New Zealand.

Stalker is associate director for technical services at the Huntington Library in San Marino, California. Her previous positions include assistant director for bibliographical projects at the Center for Bibliographical Studies and Research, University of California, Riverside; and assistant director and catloger at the EighteenthCentury Short Title Catalogue/North America.

Joe Springer, chair of the award committee, said. "The authors succeed in addressing com- plicated, technical issues in a clear and comprehensive manner. This enables a broad variety of readers - catalogers, administrators, public service and general library systems personnel-to benefit from the information the authors present."

The award, $\$ 1,000$ and a certificate donated by Christie, Manson \& Woods, Inc., will be presented at the RBMS program during the ALA Annual Conference in San Francisco, Saturday. June 28 at $8: 30$ a.m.

\section{Exhibition catalogs recognized by Leab Awards}

Two catalogs have been selected as recipients of the Katharine Kyes Leab and Daniel J. Leab American Book Prices Current Exhibition Catalogue Awards for 1997. In category one (expensive) the winner is the Pierpont Morgan Library for From Jackson to Lincoln: Democracy and Dissent, written by Robert Parks, Christin

\section{(Guidelines cont. from page 333)}

f. Are the library and information needs of undergraduate students represented adequately in the budget process?

g. Does the undergraduate library's personnel have discretion and control of its budget?

h. Do staffing and budget allocations allow for long-term planning initiatives?

\section{Reassessment}

Evaluation and assessment is a continuous process in undergraduate libraries because of the changing nature of their primary clientele and the curriculum. Communication with the overall library administration and with campus groups is a critical factor. In addition to these ongoing evaluation processes. the performance of undergraduate libraries should be periodically subjected to formal reviews. Reviews will vary depending on the mechanisms adopted by the parent institution. Findings from evaluations should be written and widely discussed in order to solicit involvement by students, faculty, and other library units. The outcome of reviews should be a reassessment of the goals and objectives of undergraduate libraries. Realistic goals and expectations of future services to be offered by undergraduate libraries should be developed. By this process, the university, the overall library system, and the undergraduate library should maintain a balance between resources and mission. 